\title{
Textos tropicais
}

\author{
Antonio Risério
}

Uma cultura é feita de várias, como aquele sujeito plural de que falava Jung - sujeito que se constitui num jogo permanente de personalidades parciais e alternativas, algumas delas em posição de dominância, outras recalcadas, pulsando em guetos underground. O observador cultural, diante dessa realidade múltipla e móvel, deve tentar desmontar as armadilhas da personalidade cultural dominante e dispor suas antenas de modo a poder captar a maior variedade possível dos sinais culturais emitidos aqui e ali. $\mathrm{O}$ problema é ainda mais complexo se o tema em tela for uma cultura do Novo Mundo.

Essas obviedades me ocorrem no momento em que penso sobre a história do texto em nossos trópicos. O início da criação textual no Brasil, ao contrário do que nos costumam dizer críticos e historiadores literários, não é assunto que se resuma à literatura. Inclui ainda textos indígenas, textos africanos e híbridos nascidos desse ménage à trois. Estudando o texto criativo nos trópicos brasileiros, será melhor não privilegiar, em princípio, uma forma textual específica, vinda neste ou naquele movimento migratório. É preciso sondar as diversas codificações textuais que aqui se moviam. Identificar a procedência dos elementos culturais em jogo no espaço superestrutural da colônia, rastreando a rota pela qual eles chegaram até aqui e mapeando seus lugares e funções na sociedade que então se organizava sob a gerência dos portugueses.

Jakobson afirmava que a poesia é um "fato inelutável". Deixando de lado, taticamente, a expressão "poesia", digamos que o texto criativo é um fenômeno universal de linguagem. Uma prática sígnica, um trabalho realizado sobre os materiais da própria linguagem, encontrável nas mais variadas formas de vida e experiência social. Dos kariris do Nordeste brasileiro aos africanos do Daomé, de zunis e maias a maoris e cunas, ora livre ora presa a cantos e danças (sincretismos palavra-som/palavra-gesto), uma linguagem é elevada à segunda potência, recebendo feição peculiar. Usando livremente e fora de contexto uma distinção de Max Bense, o texto criativo não é algo que se faz na linguagem, mas com a linguagem. Pertence por isso mesmo aos "sistemas modelizantes secundários", rubrica sob a qual os semioticistas russos agrupam "as estruturas de comunicação que se sobrepõem ao nível lingüístico natural" (Iuri Lotman). Escapando à andadura lógico-discursiva e transcendendo os objetivos puramente pragmáticos da comunicacão cotidiana, criativo é o texto que se instala, como bem disse Valéry, na floresta encantada da linguagem.

E é bom não reduzir o universo textual criativo da humanidade a um conceito culturalmente restritivo desta prática de linguagem. Cada cultura codifica à sua maneira o espectro textual que conhece. São segmentações específicas. Não devem ser utilizadas indiscriminadamente além dos limites do seu contexto original. Por que falar em literatura a propósito de uma narrativa kamaiurá, por exemplo? O próprio conceito "mito", tão usado em antropologia, pode ser perigoso para o analista textual - além de estranho à codificação textual em vigor na sociedade em que o suposto "mito" se produziu, o conceito integra uma rede lexical altamente suspeita; um circuito lingüístico-ideológico
ANTONIO RISÉRIO é poeta, ensalsta, letrista, editor da revista Padé e diretor do CERNE. É autor de As cores vivas (Fundação Casa de Jorge Amado), Carnaval ljexá (Editora Currupio) e $O$ poético e o Polftico (Editora Brasiliense), em co-autoria com Gilberto Gil. 


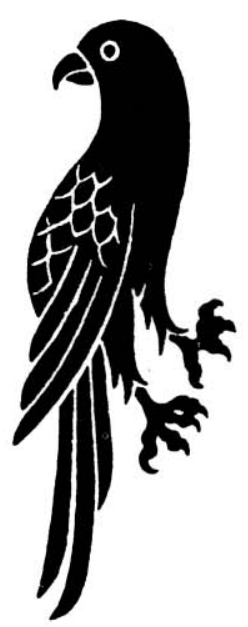

que estabelece uma conexão imediata entre o "mítico" e o irreal. O cientista social pode se contentar em declarar a natureza ficcional daquilo a que chama "mito". O intelectual ocidental funde "mito" e ficção porque o pensamento greco-romano-judaicocristão balizou o espaço em que ele se move. O logos derrotou o mythos na preferência dos pensadores gregos. Para o judeu-cristianismo, mito é todo mito que não consta do repertório de mitos da Bıblia... Mas não é bem isso o que interessa ao observador textual, esta espécie de estranho astrônomo dos corpos e sistemas verbais.

Vejamos. Os pawnees, segundo Mircea Eliade, distinguem duas categorias textuais: os textos que narram coisas que realmente aconteceram, envolvendo a criação do universo, a performance dos heróis astrais, etc. (tudo aquilo que só uma pessoa que não fosse pawnee chamaria "mito"), e os textos que narram eventos fictícios, o fabulário profano povoado pelas aventuras do coiote. Os cherokees (EUA) e os hererós (África) parecem fazer a mesma distinção. Também os iawalapitis, índios de língua aruak que integram o sistema social xinguano, consideram absolutamente reais suas narrativas "míticas". Os iawalapitis parecem organizar seus textos em duas classes (a informação ê de E. B. Viveiros de Castro que, como Eliade, limita-se a registrar a classificação de estruturas narrativas), separando o modo textual awnati (que não deve ser traduzido por "mito") do modo textual inutayá, traduzível por história e por estória. Se generalizássemos esta classificação, não haveria maior diferença entre Marx e Proust - ambos pertenceriam ao modo inutayá. Mas seria bobagem classificar Proust na modalidade textual inutaiá, ou tratar como "literárias" as narrativas awnatis. Cada cultura possui seus próprios modelos da criação textual. Existe um modo textual inutaiá na cultura iawalapiti, assim como existe um modo textual literário na cuitura ocidental-européia.

Não sei o roteiro histórico do texto inutaiá, talvez. enraizando-se em direção a milenares migrações paleoasiáticas. Mas a literatura chegou aos trópicos a bordo de alguma caravela lusitana, quando as naus do capitão Cabral cruzaram o Atlântico para coroar o velho sonho expansionista dos Avis. Seus primeiros praticantes, entre nós, foram os catequistas da Companhia de Jesus. Mas, como todos sabem, não se trata de uma criação portuguesa, e sim de uma forma cultural que chegou à Península Ibérica na expansão ocidental do Império Romano. Está na Grécia o ponto de partida da literatura (dizer "ocidental", no caso, seria redundante). Lá se encontram os modelos práticos e teóricos, os temas centrais da cultura literária, reconhecíveis em suas metamorfoses e desdobramentos posteriores. Trata-se de uma poética historicamente solidária, como já se disse. E é por isso que Wimsatt e Brooks podem insistir no princípio da continuidade e da inteligibilidade na história dos problemas literários, sublinhando que figuras tão diversas quanto Platão e Croce estão intimamente relacionadas, já que se ocupam de "uma realidade comum".

O conceito "literatura" recorta apenas uma certa região da práxis verbal criativa. Certos objetos de linguagem são agrupados numa classe " $x$ " ou " $y$ " pela tipologia européia. Nesta cirurgia, a determinação histórico-social é clara. A literatura tem o seu espaço reservado; sua função social balizada com relativa nitidez. Para um lingüista, pode não haver maior diferença, na generalidade da técnica verbal empregada, entre um texto de Lorca e um texto litúrgico ioruba. A "função poética da linguagem" (Jakobson) é detectável tanto nos mantras sânscritos quanto nos cantos nordestinos sobre a maconha. Lévi-Strauss está certo. É teoricamente possível, à metáfora poética, alcançar a "eficácia simbólica" de um texto xamanístico dos cunas do Panamá. Mas esta possibilidade é descartada, na prática, pelos modos de produção e consumo que regem o conjunto textual chamado literatura. O canto do xamã funciona, cura, porque esta é a sua raison d' être; a razão social de sua existência. A literatura tem outra destinação, seja ela definida em termos hedonísticos ou didáticos. Repito: literatura é um produto cultural europeu, com sua marca ideológica de nascença, seu vasto e dinâmico repertório formal, suas técnicas e truques, gramáticas e matrizes, variando escalas

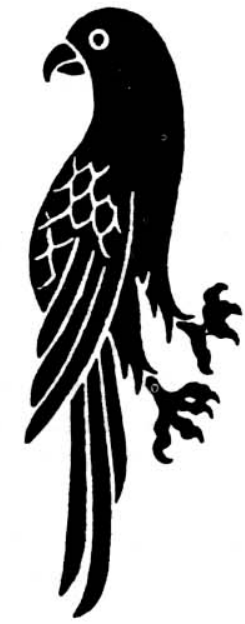


em função de escolas. E literatura brasileira é a soma das modificações históricas que uma forma cultural européia experimentou em sua inserção na realidade tropical sob domínio lusitano.

Mas a história da linguagem, nas terras atualmente brasileiras, não tem o seu ponto de partida na língua portuguesa. Antes de 1500 , nossa floresta de sons era povoada por um elenco razoável de línguas indígenas. Se mais de uma centena dessas línguas ainda são faladas hoje em dia no Brasil, podemos supor que, naquela época, seu número fosse bem maior, com o tupinambá predominando na faixa costeira. Em termos lingüísticos, o que se deu no litoral braślico, nos primeiros dias coloniais, foi o encontro entre representantes estruturados e complexos da família românica e da família tupi-guarani. Língua de contato entre índios e europeus naqueles tempos de conquista e colonização, o registro escrito do tupinambá, ou tupi antigo, data do século XVI, com as obras de Léry e Thevet. E há indícios de que não era nada insignificante o seu uso criativo.

No "Tratado descritivo do Brasil em 1587", escrevendo sobre os tupinambás da velha Kirymure, atual Bahia de Todos os Santos, Gabriel Soares de Souza emprega diversas vezes a expressão "grandes cantares" - e em todas estas vezes estamos diante da presença do texto na dança e na música. Pelo número e variedade de situações em que tais cantares aparecem, conclúmos que era intensa a comparência da "poemúsica" na vida social tupinambá. Aqueles índios, "muito alegres de rosto" e "muito amigos de novidades", possuíam um rico repertório de cançōes. "Este gentio é muito amigo do vinho", escreve Gabriel Soares, e "o bebem com grandes cantares, e cantam e bailam toda uma noite às vésperas do vinho, e ao outro dia pela manhã começam a beber, bailar e cantar". Gabriel Soares - "esprit scientifique étonnant pour son époque", no julgamento de Alfred Metraux - informa ainda que os tupinambás, homens e mulheres, "se prezam de grandes músicos". E mais: "entre este gentio são os músicos mui estimados, e por onde quer que vão, são bem agasalhados, e muitos atravessaram já o sertão por entre seus contrários, sem lhes fazerem mal".

Em meio aos cânticos referidos no relato etnográfico de Soares, podemos distinguir os cantares guerreiros e os cantares fúnebres. O cronista nos diz, por exemplo, que nas noites anteriores à partida para uma expedição bélica, o chefe indígena andava pela aldeia exortando seus companheiros à bravura, pois assim ficariam

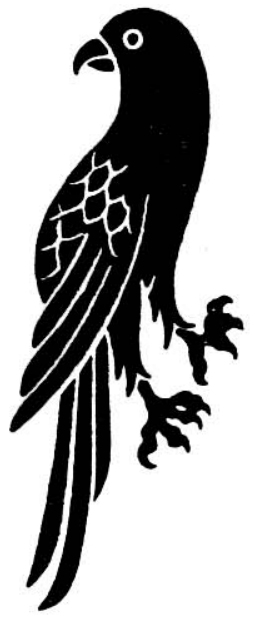
gravados na memória tribal "para os que após eles vierem cantar em seus louvores". O tupinambá que matava um inimigo era premiado com um novo nome e uma série de "novas cantigas, fundadas sobre a morte daquele que morreu, e em louvores do que matou". Entre esses cantares guerreiros, destacam-se ainda os cantares antropofágicos "vituperando o que há de padecer e exalçando o matador". Quanto aos cantos fúnebres, executados em função da morte do "principal" ou de sua mulher, Soares assinala que aí se cantam "as proezas do defunto ou da defunta". Infelizmente, nosso cronista concluiu o seu "Tratado" sem registrar um só documento musical ou textual desse cancioneiro tupinambá que tanto prendeu a sua atenção. E assim o texto tupinambá, na expressão de suas lyrics, nos escapa.

É geral a impressão de que os tupinambás eram bons músicos. E a informação de que o grande músico indígena podia atravessar os campos, sem ser molestado por seus adversários, $\varepsilon$ confirmada por outros cronistas. Fernão Cardim chega a dizer que os cantores não eram canibalizados quando caram prisioneiros. Mas o que importa sublinhar, a partir das informaçōes de Gabriel Soares, é o fato de que o repertório tupinambá era um repertório em movimento. In progress. Dinâmico - e não estacionário, como se costuma conceber o patrimônio das criações simbólicas das sociedades ágrafas. Para incitar os guerreiros à luta ou louvar os feitos de um cacique que acabara de falecer, os tupinambás tinham que ser produtores textuais. Poderiam partir da tradição, recorrendo a motivos do imaginário tribal (por falar nisso, ainda hoje não sabemos o que realmente significa "tribo"), inclusive de caráter religioso, mas o jogo verbal não estava feito ab initio e para sempre. Era preciso lançar os dados. Criar. Em outras palavras, a criação estética não se achava estagnada; não só admitia como exigia a iniciativa nova. É isto o que sobressai. Mas não só. Os tupinambás sabiam executar criaçōes de outros povos, incluindo-as no seu repertório. Conta Yves d'Évreux que, numa apresentação em que entoaram louvores aos franceses, estes índios dançaram não ao seu modo, mas no estilo de uma 
outra nação indígena. Foi o poracéu-tapoui, isto $e$, a dança dos tapuias - disseram a d'Évreux. E a verdade do improviso não parece ter nada de raro. Estas canções - tematizando árvores, pássaros ou batalhas -, com suas melodias e seus estribilhos, nasciam dia após dia. Bem recentemente, Curt Niemuendaju nos diz que sempre que um índio apapocuva recebe (digamos assim) por inspiração um novo canto, corre imediatamente para ensiná-lo à aldeia.

Ocorre que o texto ameríndio foi falsificado, traído e silenciado. Fundamentalmente, por obra e graça de missionários. Podemos retomar aqui uma útil distinção feita por Mattoso Câmara Jr., entre missionários lingüistas e missionários religiosos. De uma parte, os missionários lingüistas transformaram o tupi em função do ideal de uma gramática universal, cuja estrutura estaria desenhada no latim. "Daí resultou que a disciplinização da língua TUPI, encetada pelos missionários, obedeceu ao objetivo de aperfeiçoar a língua indígena; o que quer dizer que o missionário lingüista foi catequético tanto quanto o missionário religioso. Da mesma sorte que se queria melhorar os costumes, o espírito, a moral, a religião do índio, também se pretendia melhorar-lhe a língua", escreve Mattoso em sua "Introdução às línguas indígenas brasileiras". O tupi não era uma realidade lingüística interessante em si mesma, mas apenas veículo para converter os índios à doutrina cristã. $\mathrm{E}$ veículo que deveria ser, ele mesmo, aperfeiçoado segundo o modelo gramatical fornecido pelo latim.

De outra parte, os missionários religiosos eram pragmáticos. O tupi jesuítico era um tupi simplificado para fins de propaganda religiosa. Tratava-se de uma estratégia geral: o problema lingüŕstico foi uma das questões centrais das políticas culturais das coroas espanhola e portuguesa para as Américas Central e do Sul. Lembra o escritor paraguaio Bareiro Saguier que houve aqui "uma opção tática lingüística", pensada e medida em termos de penetração político-cultural. Em vez de promover a supressão violenta dos idiomas dos dominados, fossem eles taínos ou tupinambás, cumpria assimilar as suas falas para fins de catequese - o que, de resto, acabou produzindo involuntariamente um fenômeno único nas Américas: o bilingüismo paraguaio. $E$ que missionários não tenham se inclinado à recriação, em português ou espanhol, da textualidade ameríndia, é coisa perfeitamente compreensível. O missionário é um homem que, para converter alguém, tem que estar absolutamente convencido de que é o portador da verdade. Seguro, portanto, de que a sua cultura não é somente superior às demais, mas solitária no crédito e na reverência que merece. Isto explica o descaso missionário diante da textualidade tupinambá. Assim como, para o missionário lingüista, a língua tupinambá não era uma entidade atraente em si mesma, também para o missionário religioso o discurso tupinambá não interessava enquanto tal. O primeiro queria conformar o tupi ao latim; o segundo, traduzir a palavra cristã em palavra corrente tupinambá. Daí as gramáticas, vocabulários e catecismos produzidos nos séculos XVI e XVII, que em sua proliferação apontam sempre para o mesmo vazio informacional: a ausência de registros do texto indígena. Aprende-se a língua do gentio para melhor silenciá-lo.

Pensemos, por um instante, no bê-a-bá. O processo da comunicação, para que se complete, solicita um emissor e um destinatário. $O$ primeiro codifica a mensagem enviada ao segundo. Para que a mensagem seja decifrada, é preciso que o destinatário conheça o cơdigo. É o a-bê-cê da comunicação. Acontece que os jesuítas lusitanos não estavam dispostos a agir como decodificadores das mensagens silvícolas. Recusavam a possibilidade de partilhar códigos. Em tais circunstâncias, um etnógrafo se esforçaria para se comportar como um lingüista. Em primeiro lugar, adotando a técnica criptanalista, tentaria deduzir o código a partir da mensagem. Mas seu objetivo último seria, em princípio, chegar a ser um decodificador. Os jesútas não fixaram esta meta. Não estavam interessados no código enquanto tal, nem atentos para as mensagens. Estas não possuíam, para os missionários, o valor de mensagens. Os padres buscavam "ganchos" onde pendurar as suas idéias. Não só estavam desinteressados em captar relaçōes entre mensagem e código, como não se dispunham a examinar os nexos estabelecidos entre os elementos constitutivos de uma dada mensagem. Buscavam, antes, um bit de informação que pudesse ser "cavalgado", isto $\epsilon$, ao qual fosse possível sobrepor um elemento do código missionário.

A mensagem indígena foi assim submetida a um leitor que não estava disposto a lêla. A um falso leitor. A alguém que nela buscava o que nela inexistia, lutando para achar a fresta onde intrometer o fragmento de uma outra mensagem, revertendo a direção do processo comunicativo. O missionário nunca reconheceu, no índio, um emissor de mensagens. Quis sempre reduzi-lo ao papel do destinatário. E esta é a diferença que 
podemos flagrar entre a Relación de Ramon Pané (o primeiro livro escrito nas Américas, 1498) e o Diálogo sobre a conversão do gentio, desempenho barroquizante de Manoel da Nóbrega na estrutura clássica do diálogo platônico. Mas este é o espaço do silêncio - e cumpre falar da traição. Coisa que fica bem clara quando apreciamos o encontro do padre e do pajé. Nenhum tratamento da comunicação intercultural brasileira pode margear este fato. Padre e pajé ocupavam lugares similares em seus contextos sociais de origem. Eram possuidores de um saber que os autorizava a transitar na esfera do sagrado. Tanto os xamãs ameríndios quanto os sacerdotes europeus perceberam de imediato a situação. Pacamonte, em conversa com Yves d'Évreux, chama aos padres pay, uma das variações do vocábulo "paje”, e confessa sua curiosidade em relação aos sacerdotes. Também este soube reconhecer, em Pacamonte, o indivíduo portador de um saber especial, que o distinguia e lhe dava ascendência sobre os seus companheiros tribais. Mas havia uma diferença. $O$ capuchinho d'Évreux sugere que o trabalho catequético deveria se concentrar na conversão de pajés. A cristianização de um xamã resultaria na conversão dos índios que o veneravam. Hoje vemos o grão-rabino Sirät observar que a conversão significa a mutilação do ser espiritual da pessoa que se afasta da religião dos seus pais. Mas aqueles missionários não estavam preocupados com isso. $\mathrm{E}$ aqui se grava a diferença inesquecível. Pacamonte queria conhecer o capucho. Este só estava interessado em converter o mago do Maranhão.

D’Évreux não se desvencilha do proselitismo. Se o pajé via no padre um seu semelhante, a recíproca não era verdadeira. Para o sacerdote europeu, compará-los seria uma blasfêmia. E nesta diferença, onde verificamos a síndrome da militância missionária adquirida, desvela-se a natureza das relações que envolveram tais personagens. Os missionários não conseguiram vislumbrar, no índio, sequer um indício de interlocutor. Quando François de Razilly chegou ao Maranhão, na segunda tentativa francesa de estabelecer uma colônia no Brasil, um chefe tupinambá proferiu um discurso que foi reproduzido por Claude d'Abbeville. Mas a impressão que temos é que o capuchinho foi o redator da fala do morubixaba, transformando-o em porta-voz dos desejos do expansionismo francês. Traído pelo capucho, o discurso de Japiaçu apenas confirma as expectativas dos recém-chegados. É um discurso da rendição integral: "Nossos filhos aprenderão a lei de Deus, vossas artes e ciências, e com o tempo se tornarão vossos iguais; haverá alianças de parte a parte, de modo que já ninguém pensará que não somos franceses". Ora, o desejo tupinambá seria então desaparecer gradual e pacificamente como povo, cultura e sociedade - em função da política do governo francês! É possível que um morubixaba tenha dito isso, com estas palavras e em tal rendilhado retórico? Duvido. Não estou querendo dizer que os tupinambás não tenham se aliado aos franceses, mas que considero fantasiosos os termos aí usados, especialmente tendo em mente que Claude d'Abbeville sempre puxava a brasa para a sua pititinga. Nunca hesitou em falsear os fatos, desde que fosse da conveniência de sua ordem religiosa e de
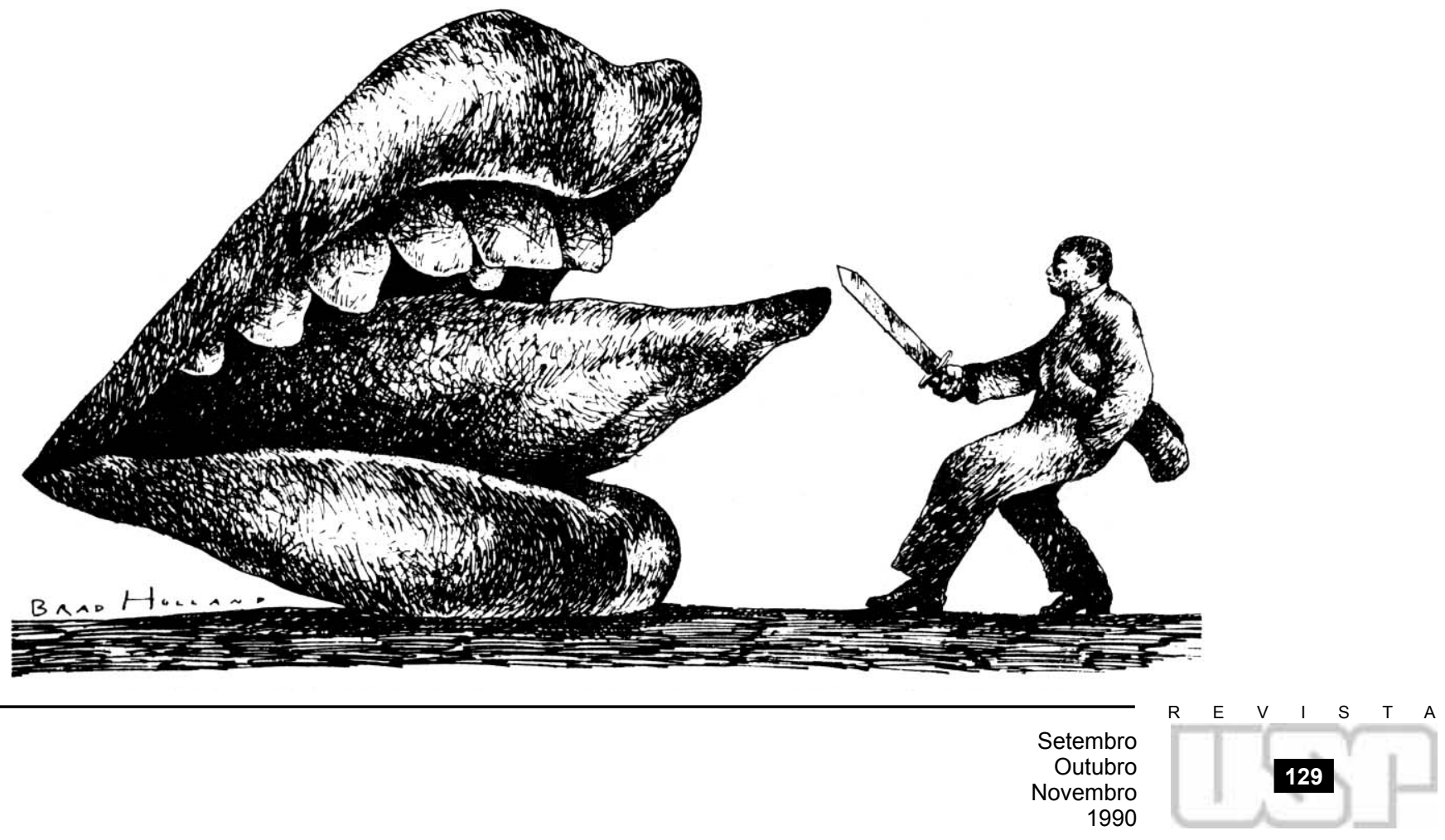
sua querida França. Rodolfo Garcia chamou a nossa atenção para o fato, a propósito de episódios ocorridos na ilha de Fernando de Noronha. É bom lembrar ainda que o discurso de Japiaçu não foi o único texto indígena que o capuchinho traiu. Ele "traduziu" ainda um discurso de Itapucu em Paris - só que, desta vez, cometeu a imprudência de registrar também o original e foi pilhado em impedimento pelo já citado Rodolfo Garcia. Para usar uma expressão cunhada por Haroldo de Campos, Claude d'Abbeville bem merece o título de "verbifalsário".

Diderot, em seu Suplemento à viagem de Bougainville, toca rapidamente no problema da tradução de textos indígenas. Neste diálogo, comentando o suposto discurso de um ancião do Taiti, o interlocutor A denuncia, na fala do velho índio, a presença de "idéias e construções européias". Em resposta, o interlocutor B explica que tais intromissões decorrem das vicissitudes da tradução - do original para o espanhol e daí para o francês. Dá-se então o assunto por encerrado. Mas aí começa o problema. O que Diderot pretende, por um truque fácil, é tornar convincente o que não convence ninguém. Temos á́ um artifício que permite ao filósofo, no diálogo imaginário entre o taitiano Oru e o capelão La Vèze, enfronhar um selvagem em discussões sobre "educação doméstica", "costumes públicos" e "qualidade do líquido seminal". Diderot não disfarça sequer o seu cientificismo. Crítica ao modo de vida europeu, o discurso do ancião de Diderot reedita o discurso do ancião tupinambá de Jean de Lêry, que põe em xeque a ambição, o excesso egocêntrico, o desejo desmedido de riqueza individual, o instituto da herança, enfim, a loucura social da França quinhentista.

Mas voltemos ao discurso de Japiaçu/Abbeville. Não há dúvida de que um texto foi traído ali, mas é preciso ver em que sentido. O que temos não é a traição inerente a toda tradução. Não se trata da interferência de um sistema lingüístico sobre outro, lugar-comum do bilingüismo e, conseqüentemente, da atividade tradutora. A questão não se prende à urdidura retórica ou aos limites das superfícies conceituais específicas de cada campo idiomático, nem foi o capuchinho imprensado por qualquer dificuldade filosofica insuperável. Resta a questão antropológica. Georges Mounin está certo quando diz que a tradução é uma arte que envolve problemas lingüísticos e etnográficos. As significações lingüísticas não se descolam do seu contexto humano - e "todo tradutor que, de mil maneiras empíricas, não se tenha transformado em etnógrafo da comunidade cuja língua traduz, é um tradutor incompleto". O revelador é que Claude d'Abbeville estava teoricamente em condições de responder a estas exigências, inclusive por conhecer in loco a situação cultural tupinambá. Mas o capucho adota uma postura oposta à do etnógrafo. Diga-se ainda que ele era um bom observador. Dos corpos indígenas aos arranjos estelares, tal como concebidos pela astronomia tupinambá, sua observação foi segura e relativamente pormenorizada. Por que então a traição do texto indígena? Simples. Ele estava usando Japiaçu para enviar uma mensagem à Europa - à classe dirigente francesa e aos seus superiores e colegas de ordem religiosa. O caráter desta mensagem é o de uma confirmação: a França acertou em cheio ao investir no Maranhão. E quem diz isso é o próprio índio...

E diferente do caso de Montaigne. Este não trai, falsifica. E Afonso Arinos flagrou no ato. Na parte dos Essais que dedica a uma reflexão algo irresponsável sobre os "canibais", Montaigne nos brinda com as letras de dois cantos indígenas do Brasil. Depois de frases e frases copiadas de Léry, sem citar a fonte, o filósofo apresenta as suas duas jóias poéticas. E é impressionante a seriedade com que mente, inclusive assinalando o feitio anacreôntico de um dos textos. Quem quer que conheça o assunto, sabe que aqueles dois textos não são tupinambás. Foram escritos pelo próprio Montaigne. O que, de resto, me faz ler com olhos oblíquos uma outra passagem dos Essais, ali onde o exaluno do Colégio de Guyenne confessa: "quem apontar algum erro atribuível à minha ignorância não fará grande descoberta, pois não posso dar a outrem garantias acerca do que escrevo".

Mas deixemos Montaigne de lado. É evidente que há muito mais o que falar acerca da textualidade ameríndia. Mas como isto aqui não é uma tẹse, e sim um escrito breve e assistemático, passo adiante para falar rapidamente do texto africano. Em seu pequeno Roteiro da literatura angolana, Carlos Ervedosa parte dos textos angolanos mais antigos. Refere-se, em especial, à classificação do texto quimbundo, estudado pelo missionário Héli Chatelain. Autor de Folk-tales of Angola, Chatelain observa que esses bantos distinguem seis tipos de texto: $m i$-soso, as ficções tradicionais; maka, narrativas reputadas verdadeiras; ma-lunda ou mi-sendu, crônicas históricas consideradas "segredos de estado" e conhecidas apenas fragmentariamente pelos plebeus; ji-sabu, os provérbios; 
mi-imbu, classe onde se agrupam, "de mãos dadas", a poesia e a música; e ji-nongongo, as adivinhas. Como se vê, trata-se de uma codificação textual própria e o elenco de formas é variado.

Também entre os iorubanos vamos encontrar esta relação íntima entre texto e música. Akin Euba, estudando o tema, vai logo avisando que, na tradição iorubana, poesia e música não são praticadas como artes distintas. Na verdade, lembra Euba, o fato do ioruba ser uma língua tonal, ondulando em três tons dotados de função semântica, já confere, à própria fala iorubana, característica de fala cantada ou canto falado - e assim o texto criativo é em si mesmo um discurso que está a meio caminho entre a fala e a canção. Uma espécie de música vocal. E como os tons da língua participam da inteligibilidade do texto, não podem ser neutralizados pelos tons da música, o que às vezes cria um conflito semiótico que geralmente se resolve pela subordinação da melodia às regras tonais da fala. Euba conclui que o estilo melódico deriva então da construção lingüística. E é bom lembrar que os próprios termos "poesia" e "música" não possuem equivalentes exatos na cultura iorubana. Foram adotados em conseqüência da assimilação da tradição européia. Hoje, os iorubanos empregam a expressão ewi para designar, de modo genérico, a forma poética. Mas não parece que a escolha seja muito adequada, já que ewi remete, mais estritamente, aos textos entoados em celebração aos ancestrais - ou eguns (ainda hoje cultuados no Brasil).

É impressionante o número e a diversidade de formas que o texto criativo assume na cultura iorubana. Podemos falar dos textos de Ifá, Ijalá, etc., etc. Para se ter uma idéia, Olabiyi Yai encontrou, em apenas um grupo iorubano, os manigiis do Daomé Central, cinco gêneros textuais específicos. Gêneros exclusivamente manigiis, apesar dos seus parentescos com outros gêneros encontráveis na chamada Iorubalândia. Embora não deseje cansar o eventual leitor com enumeraçōes intermináveis, sintetizo o inventário de Yai apenas para que se tenha uma noção da riqueza textual dos iorubanos, um dos povos mais influentes na formação da cultura brasileira. Vejamos, então. Ewố é um gênero executado somente pelos caçadores, em cujo acompanhamento entram cornetas de chifre de búfalo. Seus executantes são especialmente treinados por artistas mais velhos. O treinamento, embora não tão rigoroso como aquele exigido no caso de Ifá, implica disciplina e uma série de obrigações (sempre existiram poetas profissionais entre os iorubanos; Bolanle Awe escreve: "Para os bardos profissionais há um rigoroso sistema de treinamento e aprendizagem, antes que sejam julgados competentes para fazer exibições públicas. Um novato é normalmente ligado, em idade juvenil, a um bardo famoso, para aprender a profissão e o repertório de poemas"). Estruturalmente, ewô é um gênero verbo-musical em que cada peça é composta de três partes: a) "identificação-assinatura" - três linhas que nomeiam o gênero e o autor da composição; b) uma série de referências a poetas-caçadores que contribuíram, direta ou indiretamente, para a formação do executante; c) seção composta por vários orikis (ver adiante). Ao contrário de ewô, gênero masculino, lá é executado somente por mulheres, no tradicional padrão solistacoro, e em sua origem estava vinculado a ritos de excisão. Assokê é outro gênero, cujas peças trazem sempre uma introdução apresentando a orquestra, pelo seu lugar de origem ou pelo seu oriki. Sua parte principal - que Yai classifica como operação intertextual é uma montagem de provérbios, orikis, etc. Existem ainda ogu, gênero também executado por caçadores, e waya, igualmente tematizando provérbios, anedotas e orikis, mas que se distingue pelo grau de elaboração melódica.

Cabem aqui umas duas palavras a respeito do tão citado oriki. Para isso, vou me basear em dois estudos de Bolanle Awe-Praise poems as historical data: the example of the yoruba oriki e Notes on oriki and warfare in Yorubaland. Awe escreve que o item mais importante da criação textual iorubana é a poesia, "for almost every aspect of Yoruba life finds expression in poetry, and poetry is the most popular literary form for marking important occasions - weddings, births, funerals, naming ceremonies, festivals, etc - in Yoruba life". E o corpo central dessa poesia é constituído pelo oriki, poema de louvor, saudação poética, dirigida publicamente a um objeto. Acrescenta o estudioso que virtualmente todo objeto, animado ou inanimado, pode ter um oriki: deuses, animais, famílias, cidades, etc. $\mathrm{O}$ fato é que a presença do oriki permeia todos os aspectos e movimentos da vida iorubana. Tanto pode ser tocado de manhã para saudar um chefe na hora do despertar, como ser uma saudação verbal trocada entre membros de uma familia que se encontram pela primeira vez no dia. Os orikis de cidade (oriki ilu) falam de sua fundação, das vicissitudes de sua trajetória, da sua imagem entre as cidades vizinhas, etc., assim como os orikis de linhagem (oriki orilê) dizem das caracte- 
rísticas salientes de uma família, destacando traços dos seus membros principais. $\mathrm{O}$ oriki tanto pode ser cantado, como recitado ou percutido. Escreve ainda Bolanle Awe que um oriki não é um poema feito de um só jato - vai se compondo ao longo do período de vida do seu objeto. Frases e epítetos cunhados pelos contemporâneos desta ou daquela personalidade, a propósito de farras ou de batalhas, vão se articulando textualmente numa composição. "The oriki therefore starts off as an expression of public opinion, the product of close observation of the subject, at a particular period of histoy. Since they are said publicly and on festive occasions they soon become public property and go into the repertoire of the professional bards who eventually string them into some kind of poem which has been aptly described as a body of praise units"'. Este detalhe 6 importante: vamos encontrar muitas vezes um oriki engastado em outros gêneros estéticos.

Encerrando estas notas rápidas sobre a textualidade iorubana, gostaria de falar um pouco sobre a arte verbal gélédé. O gélédé, ao mesmo tempo rito religioso e festa popular ao ar livre (a diversão pública maior dos iorubanos de Ketu), é um evento multimídia - "uma combinação da excelência iorubana em escultura, pintura, trabalhos em metal, 'costume design', sátira, poesia e música", na definição de A. I. Asiwaju. De certa forma, a arte verbal gélédé contrabalança, pelo fato de ser e ter sido produzida pelas camadas populares, o foco mais elitizante do oriki. E é uma forte fonte de crítica social, desde os tempos mais antigos até ao período de dominação colonial inglesa ou francesa, quando muitos dos seus textos funcionaram, na boa observação de Asiwaju, como lampoons, libelos poéticos. Mas o que mais particularmente nos interessa, no gélédé, é a sua provável relação com a criação estética brasileira. Fala Olabiyi Babalola Yai: "Por certo o carnaval tem origem não-africana; mas não há nenhuma dúvida ter sido ele recuperado e transformado em seu conteúdo e finalidade pelos descendentes africanos. Aqui, um paralelo se impõe entre a literatura oral do carnaval brasileiro e o gélédé, ou 'éfé ioruba'. O gélédé, que existiu na Bahia até o início deste século, é ao mesmo tempo uma cerimônia religiosa para aplacar as 'iyamu' (nossas mães mais poderosas) e uma festa popular com saída de máscaras. É, sobretudo, uma ocasião para se apresentarem poemas cantados na praça pública ou nas ruas da aldeia. O gélédé, como o cainaval, se organiza com pequenos grupos de bairro (cordão e afoxé no Brasil) que se sucedem ao longo do dia. As canções do gélédé, como as do carnaval, têm como tema a vida e os problemas da comunidade, sobre os quais os poetas lançam um olhar crítico - garridice das mulheres, rancor do amante frustrado, falhas públicas, calamidades naturais (...), tudo passado em revista. Ora, o gélédé é de origem ioruba queto. E é sabido que o grupo ioruba mais influente no Brasil é igualmente queto. Formulamos, então, a hipótese de que os grupos gélédé, em desaparecendo no Brasil, particularmente na Bahia, passaram várias de suas características (literárias e extraliterárias) ao carnaval brasileiro".

Aí está. Mas não vou ficar aqui multiplicando exemplos. Melhor retomar, a essa altura, o nosso ponto de partida. A criação textual, embora aparentemente facultativa do ponto de vista da sobrevivência ou da organização da sociedade, parece que é socialmente indispensável. Inexistem sociedades que a desconheçam. Se quiserem, podem creditar o fato na conta de algum mistério antropológico. O certo é que aqui nos encontramos diante de uma fenômeno universal. Daí a nossa afirmação enfática de que "essa forma especial da função mitopoética que chamamos literatura erudita" (J. G. Merquior) não foi a única espécie textual que aqui desembarcou ou que aqui foi praticada. A criação textual, nas terras atualmente brasileiras, começa com tupis e tapuias. S6 adiante aparecerá Anchieta, refém dos tamoios, escrevendo De Beata Virgine Dei Matre Maria nas areias de Iperoig. Primeiros literatos residentes, possuídos pelo velho espírito cruzadista medieval de cristianização do planeta, os jesuítas se responsabilizaram pela agressão cultural que foi a difusão da "luz evangélica" entre os chamados aborígenes. O mundo indígena foi desestruturado pela ação conjugada de padres e capitães. Eram trabalhos complementares. Os soldados do rei cuidavam da desestruturação política, social e econômica dos grupos tribais, cabendo aos soldados de Cristo a parte da desintegração espiritual, pela supressão de um pensamento indígena milenar e a imposição de um novo imaginário. A literatura desempenhou papel importante nesse contexto, empregada sistematicamente no trabalho catequético que procurava fazer do índio um europeu, a fim de integrá-lo na ordem social que então se implantava. Assim começa a literatura no Brasil - forma cultural européia praticada por agentes da coroa lusitana. E aqui se movendo, com objetivos ideológicos claramente definidos, na esfera da produ- 


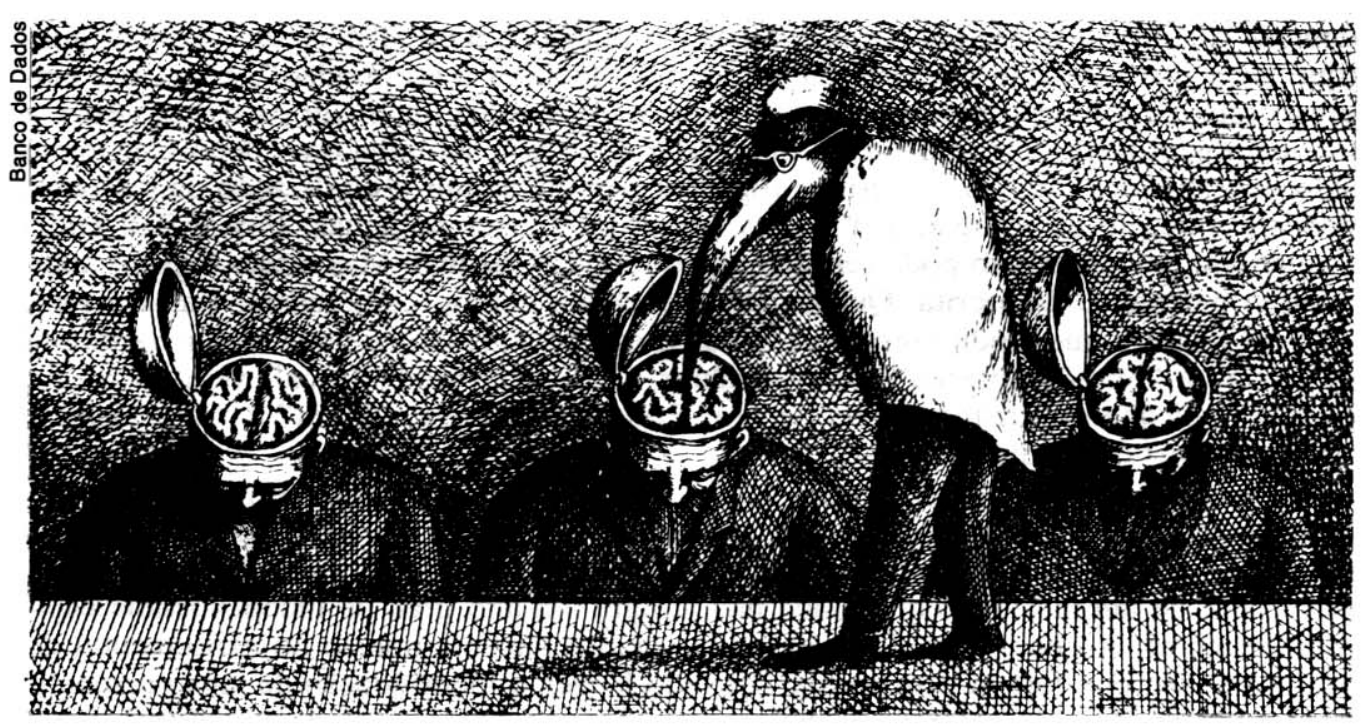

ção espiritual daqueles que, na empresa colonizadora, são identificáveis em termos de minoria étnica dominante. É fato ainda que, ao longo da era colonial, a estratificação da sociedade e o analfabetismo limitaram fortemente - como uma espécie de cordon sanitaire - o acesso ao mundo literário, de modo que os litteratti pertenceram sempre, nesse período, à classe dirigente.

Ocorre que outras modalidades textuais aqui arriaram a fateixa. E estas modalidades, que foram gradualmente destruídas ou fraturadas, compõem o desenho do capítulo primeiro da história do texto criativo no Brasil. Alceu Amoroso Lima roçou lucidamente o tema, ao observar que, desde o início do processo colonial, seria possível rastrear as peripécias de duas vertentes da "literatura" brasileira: aquela vinculada a Portugal e a do "cancioneiro espontâneo" de nosso povo. Obviamente, não é este o lugar onde eu vá discutir a tese de Amoroso Lima (não estou redigindo nenhum Tratado do Texto no Brasil), mas a verdade é que ainda hoje podemos reconhecer a presença de modalidades textuais extra-européias entre nós, especialmente, é claro, no âmbito da produção textual das classes populares. Mas, antes mesmo de entrar no exame desta seara textual, cumpre desatar o nó mistificador de certas fantasias crítico-literárias. Não faz sentido ficar atribuindo a Gonçalves Dias o título de "poeta dos índios", ou a Castro Alves o de "poeta dos escravos". Dias foi o poeta da ideologia romântico-nacionalista, assim como Castro Alves foi o poeta do liberal-abolicionismo, com gestos de alcance quasenabuquianos. Alves não conhecia em profundidade a vida negra no Brasil. E o caso de "Y-Jucá Pirama" (Dias) encerra uma anedota exemplar. Embora a ação se passe entre os timbiras, do grupo jê, Dias usou um vocabulário tupi. Além disso, o ritual da morte, ali tematizado, foi extraído da velha narrativa de Hans Staden - e é, como todos sabem, um ritual tupinambá. Por tudo isso, melhor arquivar rótulos mistificadores. $\mathrm{O}$ verdadeiro poeta dos índios cantava em sua aldeia. E o verdadeiro poeta dos escravos se encontrava na senzala, no mucambo ou no quilombo.

O problema é que, para apreciar como tais os textos de extração não-européia, os analistas textuais, formados na tradição literária, precisam superar alguns preconceitos. Dois, pelo menos - o preconceito da escrita (que se desdobra no preconceito contra a "poemúsica") e o que chamarei, ocasionalmente, "preconceito hegeliano". O fato dos textos extra-europeus não terem conhecido a codificação escrita levou o grafocentrismo a relegá-los a um plano civilizacional inferior. Em contato com os tupinambás, no século XVI, o sapateiro calvinista Jean de Léry, ainda não atingido pela má consciência colonizadora, pôde falar sem freios sobre o assunto. "Eis portanto aí um tema de dissertação suscetível de mostrar que os habitantes da Europa, da Ásia e da África devem louvar a Deus pela sua superioridade sobre os dessa quarta parte do mundo. Ao passo que os selvagens nada podem comunicar-se entre si a não ser pela palavra, nós, ao contrário, podemo-nos entender e dizer os nossos segredos, por meio da escrita, pelas cartas que enviamos de um a outro extremo da terra. Além da invenção da escrita, os conhecimentos da ciência que aprendemos pelos livros e que eles ignoram devem ser tidos como dons singulares que Deus nos concedeu'. Esta distinção é tão poderosa, tão for-

(1)

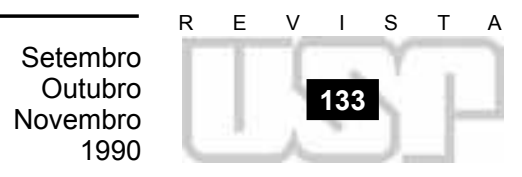


temente distintiva, que ainda hoje falamos em povos com ou sem escrita. Lévi-Strauss (que acha que a função primária da escrita foi "facilitar a escravidão", e que seu emprego estético é função secundária, "se é que não se reduz, na maior parte das vezes, a um meio para reforçar, justificar ou dissimular a outra") sublinha que, depois de terem sido desmontados todos os critérios propostos para distinguir a civilização da barbárie, persiste o desejo de se agarrar à escrita como um divisor de águas. Fica difícil então aceitar que um analfabeto pode ser um exímio produtor textual. Mas o fato é que o texto criativo independe da escrita. Quanto ao preconceito contra o sincretismo palavra-som, que daí nasce e que ainda vigora em meios literários, quando se tenta negar o estatuto de poesia à "letra-de-música", basta lembrar que a expressão "lírica" vem do grego, lyrikós, indicando o canto ao som da lira. Etimologicamente, "lírica" é "poemúsica". Arnaut Daniel que o diga.

O "preconceito hegeliano" é mais sutil e mais entranhado, mesmo porque vai se entrelaçar, ao cabo, com a suspeitíssima noção de "folclore". Embora diga que a poesia popular é uma das principais variedades da poesia lírica, o filósofo alemão sustenta que ela é obra de um indivíduo que ainda não atingiu um alto grau de independência espiritual e moral. Ao contrário, é um indivíduo completamente imerso no meio mental do seu povo. Daí que falte a esta poesia, segundo Hegel, a identificação de uma personalidade criadora, à qual possamos atribuir o poema como "emanação da sua alma". Seria o contrário do que ocorre com as "obras líricas superiores". Conclui então o filósofo: "Os cantos populares são assim produções particulares por excelência, para a apreciação dos quais não possuímos nenhum criterio fixo, visto estarem demasiadamente afastados do humano universal. Por conseguinte, o fato de termos ao nosso alcance os cantos dos iroqueses, dos esquimós e de outros povos selvagens não significa de modo algum que haja sido ampliado o círculo das nossas alegrias poéticas". Coloquemos tudo, então, na pasta do "folclore", este curioso mentefato gerado na confluência do evolucionismo e do positivismo europeus de um século que já passou.

Hegel parte da inexatidão, faz escala na fantasia e segue em direção ao subjetivismo. Mas vamos por partes. É inexato apontar a ausência, por imersão, do "indivíduo criador". Quem pretende eclipsar esta personalidade criadora é o próprio Hegel, jamais a sociedade em que ela desponta e amadurece. Antropólogos que estudaram a estatuária africana sabem disso muito bem. Há casos de escultores que se tornaram famosos - e seus estilos individuais eram reconhecidos pelos "nativos". Fantasioso é o tal "humano universal", na medida em que Hegel tem, como referência, ele mesmo. É impossível que um iroquês ou um esquimo, falando sobre o nascimento ou sobre a morte, nada tenha a nos dizer. Por fim, dizer que o acesso a textos extra-europeus em nada alarga "o círculo das nossas alegrias poéticas" é não só uma afirmação subjetiva, mas um atestado de embotamento ideológico da sensibilidade. Prefiro, no caso, a companhia do crítico inglês George Robert Coulthard e a do poeta brasileiro Augusto de Campos. Coulthard é um homem apaixonado pelos textos criados no imperio dos incas. E Augusto de Campos, talvez o maior poeta que o mundo produziu na segunda metade do século XX, escreveu: "Um dos mais espantosos poemas sobre o ciúme que conheço e que não hesito em trazer à baila, no confronto com o texto shakesperiano, pertence a um anônimo pele-vermelha". Eis o texto: "eu me pergunto/ se ela estará suficientemente humilhada - I a mulher sioux/ cuja cabeça acabo de cortar". Acrescento que, entre os cânticos do "Wubwang'u", ritual do povo ndembo do noroeste de Zâmbia (povo que, de resto, cultiva a prática da "etimologia poética" de que falava o futurista russo Khliébnikov), encontrei uma das imagens mais belas e ousadas de que já tive notícia: "uma buceta grande, um pau pequeno/ uma buceta como a testa de um leão". E vejo que a verdade é que Hegel não queria - programaticamente - ampliar o ćrculo das suas alegrias poéticas...

Mas vamos finalizar. É óbvio que concordo com Bareiro Saguier quando ele fala na "imposição final da cultura ocidental na América" e na "elevação da língua européia a meio de expressão literária". Não é isto o que estou discutindo. Reclamo apenas que o capítulo um da história do texto criativo no Brasil não pode ser uma opção lusocêntrica. Havia outros textos no ar. E só o reconhecimento da existência de textualidades extraliterárias nos permitirá não só mapear esta mesma existência, como avaliar o significado desses textos entre nós, no que sobreviveram, sobrevivem e fecundam. E o fato é que mesmo as destruições e sobrevivências fragmentárias dessas trajetórias textuais serão sociologicamente relevantes para a leitura da formação cultural brasileira, para além de qualquer exclusivismo. É dever do analista textual meditar sobre o assunto. Quando nada, para ampliar o círculo das suas alegrias poéticas. 